\title{
HAK ASUH ANAK AKIBAT CERAI GUGAT \\ DALAM PERKARA NOMOR 0915/Pdft.G/2017/PA.Bgr
}

\author{
Arnengsih, Ramdani Wahyu Sururie, Mohammad Sar'an \\ Fakultas Syariah dan Hukum, UIN Sunan Gunung Djati Bandung, Indonesia \\ E-Mail: arnengsih10@gmail.com
}

\begin{abstract}
This research is motivated by the existence of an Application for Divorce Claims in Bogor Religious Court ruling as an Applicant filing for Claims Divorce and Child Custody. The Plaintiff as a mother filed a lawsuit to the Bogor Religious Court so that Child Custody fell on the Plaintiff. But the Defendant as the father is suing back, that the child custody holder is his father because his mother does not reflect as a good mother. Then the Board of Judges of the Bogor Religious Court rejected the Plaintiff's claim and granted the Defendant's claim to establish custody of the child at the Defendant until the child is 14 years old provided that the plaintiff is given access to meet the child. This study aims to determine the legal basis of the Panel of Judges, the method of finding the Panel of Judges in child custody cases. The results of this study are: 1. The consideration of the panel of judges granted the Defendant's lawsuit because he saw from the facts in the trial and based on the evidence submitted by the parties and looked at the benefit of the child. 2. Judges use the method of legal construction in legal discovery, namely the method of law enforcement (rechtsvervinings). In this method, the judge can rule out articles that are deemed incompatible with the facts at this time.
\end{abstract}

Keywords: Child Custody, Considerations, Decisions

\begin{abstract}
Abstrak
Penelitian ini dilatar belakangi adanya Permohonan Cerai Gugat putusan PA Bogor sebagai Pemohon mengajukan Cerai Gugat dan Hak Asuh Anak. Penggugat sebagai ibu mengajukan gugatan ke PA Bogor agar Hak Asuh Anak jatuh kepada Penggugat. Tetapi Tergugat sebagai ayah menggugat balik bahwasannya pemegang hak asuh anak adalah ayahnya karena ibunya bukan ibu yang baik dan tidak mencerminkan cara hidup ibu yang baik. Kemudian Majelis Hakim Pengadilan Agama Bogor menolak gugatan Penggugat dan mengabulkan gugatan Tergugat menetapkan hak asuh anak berada pada Tergugat hingga anak tersebut berusia 14 tahun dengan ketentuan penggugat diberi akses bisa bertemu dengan anak. Penelitian ini bertujuan untuk mengetahui landasan hukum Majelis Hakim, Metode penemuan Majelis Hakim dalam perkara hak asuh anak. Hasil penelitian ini adalah: 1. Pertimbangan majelis hakim mengabulkan gugatan Tergugat karena melihat dari fakta yang ada di persidangan dan berlandaskan pada pembuktian yang diajukan oleh para pihak dan melihat kepada kemaslahatan anak. 2. Hakim menggunakan metode konstruksi hukum dalam penemuan hukumnya, yaitu metode pengkongkretan hukum (rechtsvervjnings). Dalam metode ini, hakim dapat menyampingkan pasal yang sudah dianggap tidak sesuai dengan fakta pada saat ini.
\end{abstract}

Kata Kunci: Hak Asuh Anak, Pertimbangan, Putusan 


\section{PENDAHULUAN}

Manusia diciptakan ke dunia untuk mengabdikan diri kepada Allah SWT yang merupakan bentuk dari hubungan habluminallah, dan diberi tugas untuk mengelola bumi dan segala isinya yang merupakan bentuk adanya hubungan habluminannas. Dan juga mencerminkan adanya bentuk hubungan sosial yang mengharuskan manusia untuk bermasyarakat dalam mempertahankan hidup selalu berusaha untuk memenuhi kebutuhan hidupnya.

Kebutuhan pergaulan yang sah di dunia dalam rangka melahirkan keturunan lewat perkawinan, telah ditetapkan dalam Undang-Undang Nomor 1 Tahun 1974 pasal 1 ayat 1 bahwa perkawinan adalah ikatan lahir batin antara seorang pria dengan seorang wanita untuk membentuk keluarga yang bahagia dan kekal berdasarkan ketuhanan Yang Maha Esa. ${ }^{1}$

Akad Perkawinan dalam hukum Islam bukanlah perkara perdata semata, melainkan ikatan suci (miitsaqan galidhzan) yang terkait dengan keyakinan dan keimanan kepada Allah. ${ }^{2}$ Di dalam Kompilasi Hukum Islam ditegaskan bahwa perkawinan sebagai akad yang sangat kuat (miitsaqan ghalidzan) untuk mentaati perintah Allah dan pelaksannannya merupakan ibadah sesuai dengan Pasal 2 Kompilasi Hukum Islam. ${ }^{3}$

Dalam Undang-Undang Nomor 1 Tahun 1974 Pasal 39 bahwa: Perceraian hanya bisa dilakukan di depan sidang Pengadilan setelah Pengadilan yang bersangkutan berusaha mendamaikan kedua belah pihak. Pasal 115 Kompilasi Hukum Islam menegasakan bahwa: Perceraian hanya dapat dilakukan di depan sidang Pengadilan Agama setelah Pengadilan Agama tersebut berusaha dan tidak berhasil mendamaikan kedua belah pihak.

Secara umum kewenangan Peradilan Agama sebagaimana Pasal 49 Undang-Undang Nomor 3 Tahun 2006 yang isi dan pasalnya tidak di ubah dalam Undang-Undang Nomor 50 Tahun 2009 adalah meliputi: memeriksa, memutus, dan menyelesaikan perkara-perkara di tingkat pertama antara orang yang beragama Islam dibidang perkawinan, waris, wasiat, hibah, wakaf, zakat, infak, shadaqah dan ekonomi syari' ah. ${ }^{4}$

Diantara perkara yang disebutkan di atas, maka bidang perdata perkawinan merupakan salah satu perkara yang menjadi kewenangan Pengadilan Agama. Di dalam Undang-Undang No. 1 Tahun 1974 pasal 49 ayat 2 bahwa perkawinan memiliki 22 jenis perkara, salah satunya yaitu mengenai pemeliharaan anak atau pengasuhan anak yakni terdapat pada pasal 11, 12, dan 13 Undang-Undang Nomor 1 Tahun 1974.

Anak adalah seorang yang belum berusia 18 (delapan belas) tahun, termasuk anak yang masih dalam kandungan. ${ }^{5}$ Sedangkan menurut Kompilasi Hukum Islam,

1 Subekti, Undang-Undang Hukum Perdata , 2001. h.157

2 Amiur Nurdin dan Azhari Akmal Tarigan, Hukum Perdata Islam di Indonesia (Studi Kritis Perkembangan Hukum Islam dari Fikih, UU No 1/1974 sampai KHI) (Jakarta : Kencana, 2004), h. 206.

${ }^{3}$ Beni Ahmad Saebani dan Encep Taufiqurrahman, Pengantar Ilmu Fiqih (Bandung: Pustaka Setia, 2015), h. 143.

${ }^{4}$ Ahmad Mujahidin, Prosedur Penyelesaian Sengketa Ekonomi Syari'ah di Indonesia, (Bogor, Ghalia Indonesia, 2010). h. 16.

${ }_{5}^{5}$ Undang-Uundang N0. 23 Tahun 2002 Tentang Perlindungan anak (Bandung: PT. Citra Umbara, 2003), h. 4 .

16 Jurnal Al-Ahwal Al-Syakhsiyyah : Jurnal Hukum Keluarga dan Peradilan Islam 
Arnengsih, Ramdani Wahyu Sururie, Mohammad Sar'an Hak Asuh Anak Akibat Cerai Gugat anak adalah orang yang belum genap 21 tahun dan belum pernah menikah dan karenanya belum mampu untuk berdiri sendiri.

Dalam Undang-Undang No. 23 Tahun 2002 Tentang Perlindungan anak bahwa: 1. Orang tua berkewajiban dan bertanggung jawab untuk: a) mengasuh, memelihara, mendidik dan melindungi anak; b) menumbuh kembangkan anak sesuai dengan kemampuan, bakat dan minatnya; dan c) mencegah terjadinya perkawinan pada usia anak-anak.

Pendidikan terbaik yang dapat didapatkan oleh seorang anak adalah berasal dari kedua orang tuanya, dengan memberikan kasih sayang dan cinta, serta memberikan pendidikan yang baik agar anak tumbuh subur dengan jasmani yang sehat, cerdas, berakhlakul karimah dan memilliki perasaan yang halus. ${ }^{6}$

Berdasarkan Pasal 41 Undang-Undang Nomor 1 Tahun 1974 bahwa pemeliharaan anak atau penguasaan anak merupakan salah satu perkara di bidang perkawinan yang berkenaan dengan "akibat" yang timbul dari perceraian. ${ }^{7}$

Dalam Kompilasi Hukum Islam mengatur lebih rinci tentang pemeliharaan anak yaitu dalam pasal 105 sebagai berikut dalam hal terjadinya perceraian: a). pemeliharaan anak yang belum mumayyiz atau belum berumur 12 tahun adalah hak ibunya; b). pemeliharaan yang sudah mumayyiz diserahkan kepada anak untuk memilih diantara ayah dan ibunya sebagai pemegang hak pemeliharaannya; c). Biaya pemeliharaan anak ditanggung oleh ayahnya.

Sedangkan Undang-Undang Nomor 1 Tahun 1974 tetang perkawinan mengatur dalam pasal 45 bahwa: a. kedua orang tua wajib memelihara dan mendidik anak-anak mereka sebaik-baiknya; b. kewajiban orang tua yang dimaksud dalam ayat (1) pasal ini berlaku sampai anak itu kawin atau dapat berdiri sendiri. Kewajiban berlaku terus meskipun kedua orang tua putus.

Adapun dalam realita yang terjadi di Pengadilan Agama Bogor yaitu adanya perselisihan dalam keluarga yang mengakibatkan perceraian yang berdamapak pada hak pengasuhan anak (hadhanah) seperti dalam Putusan Nomor 0915/Pdt.G/2017/PA.Bgr tanggal 27 Februari 2017. Namun dalam perkara ini hak asuh anak itu jatuh kepada bapak bukan kepada ibu.

\section{METODE PENELITIAN}

Penelitian ini menggunakan metode yuridis normatif (legal research), metode ini digunakan terhadap penelitian teks peraturan perundang-undangan dan putusan pengadilan yang telah inkracht, metode analisis yang digunakan peneliti adalah analisis

6 Muhammad Bagir Fiqh Praktis II: Menurut Al-Qur'an, Al-Sunnah, dan Pendapat para Ualama(Bandung: Karisma, 2008), h. 237.

7 M. Yahya Harahap, kedudukan Kewenangan dan Acara Peradilan Agama (Jakarta: Sinar Grafika, 2003). h. 143.

Jurnal Al-Ahwal Al-Syakhsiyyah : Jurnal Hukum Keluarga dan Peradilan Islam 17 
isi (content analysis).

Teknik pengumpulan data yang digunakan peneliti adalah studi dokumentasi, dan studi kepustakaan. 1. Studi dokumentasi yaitu mendatangi Pengadilan Agama Bogor untuk meminta salinan putusan, selain itu ada juga studi dokumentsi dilakukan terhadap dokumen penunjang putusan, baik berupa peraturan perundang-undangan maupun dokumen-dokumen yang sudah ada terhadap perkara yang diteliti. 2. pengumpulan data penelitian ini dilakukan melalui metode studi pustaka dengan cara melakukan pengolahan data yang diambil dari berbagai literatur atau buku-buku serta jurnal yang ditulis oleh para ahli, guna mendapatkan landasan teoritis tentang permasalahan yang dikaji, yakni tentang pemeliharaan anak setelah terjadinya perceraian. Studi kepustakaan ini dimaksudkan untuk memperkuat kebenaran hasil penelitian dengan cara mencari konsep-konsep yang ada relefensinya dengan masalah yang diteliti. Hal ini sesuai dengan pendapat Surachmad ${ }^{8}$ bahwa perlengkapan penelitian bila tidak ditunjang dengan kepustakaan tidak sempurna.

\section{HASIL PENELITIAN DAN PEMBAHASAN}

Hadhanah berasal dari bahasa Arab yang berarti: Hal memelihara, mendidik, mengatur, mengurus segala kepentingan atau urusan anak-anak yang belum mumayyiz (belum dapat membedakan baik dan buruknya sesuatu atau tindakan bagi dirinya). Sedangkan menurut bahasa berarti meletakkan sesuatu di dekat tulang rusuk atau di pangkuan, karena ibu waktu menyusukan anaknya meletakkan anak itu di pangkuannya, seakan-akan ibu di saat itu melindungi dan memelihara anaknya sehingga "hadhanah" dijadikan istilah yang maksudnya: pendidikan dan pemeliharaan anak sejak dari lahir sampai sanggup berdiri sendiri mengurus dirinya yang dilakukan oleh kerabat anak itu. ${ }^{9}$

Dalam istilah fiqh digunakan dua kata namun ditujukan untuk untuk maksud yang sama yaitu kafalah dan hadhanah. Yang dimaksud dengan hadhanah atau kaffalah dalam arti sederhana ialah "pemeliharaan"atau "pengasuhan". Dalam arti yang lebih lengkap adalah pemeliharaan anak yang masih kecil setelah terjadinya putus perkawinan. Hal ini dibicarakan dalam fiqh, secara praktis antara suami dan istri telah terjadi perpisahan sedangkan anak-anak memerlukan bantuan ayah atau ibunya. ${ }^{10}$

Para fukaha mendefinisikan hadhanah sebagai berikut:11

a. Ulama Hanafiyah mendefinisikan hadhanah sebagai usaha mendidik anak yang

8 Winaro Surachmad, Pengantar Penelitian Ilmiah; dasar, metoda, teknik. Tarsito: (Bandung Zakaria ahmad al-barry, 1982) h. 251.

9 Tihami dan Sohari Sahrani, Fikih Munakahat ( Jakarta: PT Raja Grapindo, 2013), h. 215. 2006), h. 328.

10 Amir Syaripuddin, Hukum Perkawinan Islam di Indonesia (Jakarta: Pernada Medua Group,

${ }^{11}$ Huzaemah Tahido Yanggo, Fikih Perempuan Kontemporer (Bandung: Ghalia Indonesia, 2010), h. 182-183.

18 Jurnal Al-Ahwal Al-Syakhsiyyah : Jurnal Hukum Keluarga dan Peradilan Islam 
Arnengsih, Ramdani Wahyu Sururie, Mohammad Sar'an Hak Asuh Anak Akibat Cerai Gugat dilakukan oleh orang yang mempunyai hak mengasuh.

b. Menurut Ulama Syafi' iyah, hadhanah ialah mendidik orang yang tidak dapat mengurus dirinya dengan apa yang bermaslahat baginya dan memeliharanya dari apa yang membahayakannya, meskipun orang tersebut telah dewasa, seperti membantu dalam hal membersihkan jasadnya, mencucikan pakaiannya, meminyaki rambutnya, dan lain-lainnya, demikian pula menggendonng anak dalam buaian dan mengayun-ayunkannya supaya dapat tidur.

Pendapat yang dikemukakan oleh ulama syafii'iyah itu hampir sama dengan apa yang diyakini oleh kelompok ulama Malikiyah dan Hanabilah. Namun, dalam kelompok ulama Hanafiyah dapat ditemukan pembagian urusan yang terkait dengan anak kecil, yaitu satu bagian diberikan kepada wali anak tersebut dan sebagian lagi pengasuh dengan tugasnya untuk mendidik.

Dengan demikian, dapat disimpulkan bahwa masalah hadhanah adalah masalah menjaga, memelihara, mengasuh, memimpin, mendidik, dan mengatur hal tentang anak yang belum bisa menjaga, mengatur dan mengurus dirinya sendiri. Yang berkenaan dengan masalah hadhanah ini terjadi jika suami isteri bercerai dan keduanya memiliki anak namun anak itu belum mumayyiz atau belum cukup umur untuk menguasai kemaslahatan dirinya, maka istri atau ibu anak tersebut yang lebih berhak menjadi pengasuh hingga anak tersebut dapat mengerti akan kemaslahatan dirinya.

Penelitian ini berdasarkan pada putusan PA Bogor No. 0915/Pdt.G/2017/PA.Bgr. Adapun duduk perkaranya secara garis besar adalah sebagai berikut:

1. Bahwa Majelis Hakim untuk memenuhi ketentuan Pasal 130 HIR. Majelis Hakim telah berupaya mendamaikan Penggugat dan Tergugat di depan sidang, bahkan Penggugat dan Tergugat telah menempuh proses mediasi sesuai ketentuan PERMA Nomor 1 Tahun 2008 sebgaimana telah diubah dengan PERMA Nomor 1 Tahun 2016 dengan Mediator Drs. H. Djedjen Zaenuddin, SH. MH. Namun upaya damai tersebut tidak berhasil.

2. Bahwa maksud dan tujuan gugatan Penggugat adalah kehendak Penggugat untuk menjadi pemegang hak asuh anak (hadhanah) terhadap anak tersebut dimana anak tersebut telah berada dalam pemeliharaan ditetapkan kepada Tergugat (Ayahnya).

3. Bahwa dalam gugatannya Penggugat memohon agar anak Penggugat dan Tergugat yang lahir tanggal 19 Februaru 2013 ditetapkan berada dalam pengasuhan dan pemeliharaan (hadhanah) Penggugat nafkah anak dan biaya pendidikan anak tersebut dibebankan kepada Tergugat setiap bulannya sebesar Rp. 15.000.000,- (lima belas juta rupiah);

4. Bahwa untuk menguatkan dalil gugatan Penggugat tentang pemeliharaan anak tersebut, Penggugat telah menyerahkan buktu tertulis berupa P.2 sera saksisaksi.

Jurnal Al-Ahwal Al-Syakhsiyyah : Jurnal Hukum Keluarga dan Peradilan Islam 19 
5. Bahwa terhadap gugatan Penggugat tentang pemeliharaan anak Penggugat tersebut, Majelis Hakim mempertimbangkan sebagai berikut: Bahwa Majelis Hakim berpendapat bahwa anak bukan merupakan objek hukum yang bisa dialihkan keberadaannya dan bukan dieksekusi akibat dari suatu keputusan pengadilan, karena peralihan tempat tinggal akan menjadi masalah tersendiri buat anak lebih-lebih anak Penggugat Rekonvensi dan Tergugat Rekonvensi dalam keadaan kurang sehat dan dalam masa terapi dan Menurut Majelis Hakim anak adalah subjek hukum yang perlu diperhatikan dan dilindungi kebutuhan hidup dan hajatnya."

6. Bahwa selama Penggugat dan Tergugat berpisah rumah sampai sekarang anak Penggugat dan Tergugat yang lahir tanggal 19 Februari 2013 tinggal bersama dan diurus oleh Tergugat.

7. Bahwa berdasarkan bukti T.31 dan T.32 diperoleh fakta bahwa perkembangan anak Penggugat dan Tergugat sekarang ini dalam kondisi membaik.

8. Bahwa saksi pertama dan saksi kedua yang dihadirkan baik oleh Tergugat menerangkan bahwa setelah Penggugat dan Tergugat berpisah dan anak dalam asuhan Tergugat sampai dengan sekarang kondisi anak dalam keadaan sehat dan perkembangnnya baik dan tidak terlantar.

9. Bahwa sebagaimana telah dipertimbangkan bahwa selama Penggugat dan Tergugat berpisah, dan selama itu pula anak tinggal bersamaTergugat dalam keadaan yang nyaman dan perkembangan kesehatan yang terus membaik dan bagus.

10. Bahwa Majelis Hakim berpendapat dan sejalan dengan kehendak dari undangundang tentang perlindungan anak bahwa kewajiban pengasuhan anak haruslah didasarkan demi kepentingan anak bukan demi kepentingan orang tuanya.

11. Bahwa berdasarkan pertimbangan-pertimbangan tersebut diatas Majelis Hakim berpendapat bahwa gugatan Penggugat mengenai kuasa pengasuhan anak Penggugat dan Tergugat yang lahir tanggal 19 Februari 2013 patut ditolak dan akan dituangkan dalam diktum amar putusan ini."

Adapun amar putusan PA Bogor Nomor 0915/Pdt.G/2017/PA.Bgr: DALAM KONVENSI:

1. Mengabulkan gugatan Penggugat Konvensi sebagian.

2. Menjatuhkan talak satu bain Sughra Tergugat (Xxxxxxxxxxxx xxxxxxxxx bin xxxxxxxxx bin Xxxxxx xxx) terhadap Ppenggugat (Xxxxxxxx xxxx Binti Xxxxxxx).

3. Menolak gugatan Penggugat Konvensi selebihnya. DALAM REKONVENSI

4. Mengabulkan gugatan Penggugat Rekonvensi

5. Menetapkan kuasa pengasuhan anak bernama Xxxxxxxx xxxxxx bin Xxxxxxx xxxxx, laki-laki, lahir tanggal 19 Februari 2013 berada pada Penggugat 
Arnengsih, Ramdani Wahyu Sururie, Mohammad Sar'an Hak Asuh Anak Akibat Cerai Gugat

Rekonvensi hingga anak tersebut berusia 14 (empat belas) tahun dengan ketentuan Tergugat Rekonvensi diberi akses bisa bertemu dengan anak tersebut. DALAM KONVENSI DAN REKONVENSI:

Membebankan Penggugat Konvensi/Tergugat Rekonvensi untuk membayar biaya perkara sebesar Rp. 461. 000,- ( Empat ratus enam puluh satu ribu).

\section{Pertimbangan Hukum Majelis Hakim Tentang Hak Asuh Anak Akibat Cerai Gugat Dalam Perkara Nomor 0915/Pdt.G/2017/PA.Bgr}

Adapun pertimbangan hukum Majelis Hakim PA Bogor adalah sebagai berikut: Pertimbangan hukum dalam rekonvensi:

1. Bahwa Majelis Hakim untuk memenuhi ketentuan Pasal 130 HIR. Majelis Hakim telah berupaya mendamaikan Penggugat dan Tergugat di depan sidang, bahkan Penggugat dan Tergugat telah menempuh proses mediasi sesuai ketentuan PERMA Nomor 1 Tahun 2008 sebgaimana telah diubah dengan PERMA Nomor 1 Tahun 2016 dengan Mediator Drs. H. Djedjen Zaenuddin, SH. MH. Namun upaya damai tersebut tidak berhasil.

2. Bahwa maksud dan tujuan gugatan Penggugat adalah kehendak Penggugat untuk menjadi pemegang hak asuh anak (hadhanah) terhadap anak tersebut dimana anak tersebut telah berada dalam pemeliharaan ditetapkan kepada Tergugat (Ayahnya).

3. Bahwa dalam gugatannya Penggugat memohon agar anak Penggugat dan Tergugat yang lahir tanggal 19 Februaru 2013 ditetapkan berada dalam pengasuhan dan pemeliharaan (hadhanah) Penggugat nafkah anak dan biaya pendidikan anak tersebut dibebankan kepada Tergugat setiap bulannya sebesar Rp. 15.000.000,- (lima belas juta rupiah);

4. Bahwa untuk menguatkan dalil gugatan Penggugat tentang pemeliharaan anak tersebut, Penggugat telah menyerahkan buktu tertulis berupa P.2 sera saksisaksi.

5. Bahwa terhadap gugatan Penggugat tentang pemeliharaan anak Penggugat tersebut, Majelis Hakim mempertimbangkan sebagai berikut:

Bahwa Majelis Hakim berpendapat bahwa anak bukan merupakan objek hukum yang bisa dialihkan keberadaannya dan bukan dieksekusi akibat dari suatu keputusan pengadilan, karena peralihan tempat tinggal akan menjadi masalah tersendiri buat anak lebih-lebih anak Penggugat Rekonvensi dan Tergugat Rekonvensi dalam keadaan kurang sehat dan dalam masa terapi dan Menurut Majelis Hakim anak adalah subjek hukum yang perlu diperhatikan dan dilindungi kebutuhan hidup dan hajatnya.

6. Bahwa selama Penggugat dan Tergugat berpisah rumah sampai sekarang anak Penggugat dan Tergugat yang lahir tanggal 19 Februari 2013 tinggal bersama 
dan diurus oleh Tergugat.

7. Bahwa berdasarkan bukti T.31 dan T.32 diperoleh fakta bahwa perkembangan anak Penggugat dan Tergugat sekarang ini dalam kondisi membaik.

8. Bahwa saksi pertama dan saksi kedua yang dihadirkan baik oleh Tergugat menerangkan bahwa setelah Penggugat dan Tergugat berpisah dan anak dalam asuhan Tergugat sampai dengan sekarang kondisi anak dalam keadaan sehat dan perkembangnnya baik dan tidak terlantar.

9. Bahwa sebagaimana telah dipertimbangkan bahwa selama Penggugat dan Tergugat berpisah, dan selama itu pula anak tinggal bersamaTergugat dalam keadaan yang nyaman dan perkembangan kesehatan yang terus membaik dan bagus.

10.Bahwa Majelis Hakim berpendapat dan sejalan dengan kehendak dari undangundang tentang perlindungan anak bahwa kewajiban pengasuhan anak haruslah didasarkan demi kepentingan anak bukan demi kepentingan orang tuanya.

11.Bahwa berdasarkan pertimbangan-pertimbangan tersebut diatas Majelis Hakim berpendapat bahwa gugatan Penggugat mengenai kuasa pengasuhan anak Penggugat dan Tergugat yang lahir tanggal 19 Februari 2013 patut ditolak dan akan dituangkan dalam diktum amar putusan ini.

Pertimbangan hukum dalam Konvensi

1. Bahwa maksud dan tujuan gugatan rekonvensi adalah sebagaimana tersebut diatas;

2. Bahwa apa yang menjadi pertimbangan dalam konvensi menjadi dasar dalam pertimbangan rekonvensi.

3. Bahwa Tergugat yang di maksudkan yaitu Penggugat Rekonvensi telah membuktikan dalam persidangannya bahwasannya Penggugat yaitu Tergugat Konvensi telah melakukan perselingkuhan dengan bukti-bukti yaitu: Fotokopi percakapan Penggugat Via Whatsaap, telah dinazegelen Pos dan dicocokan dengan aslinya. Bukti T.5, Fotokopi lembaran rajah/isim, telah dinajegelen Pos dan dicocokan dengan aslinya, bukti T.6, Fotokopi hasil tracking nomor ponsel (XL) Penggugat yang telah di non aktifkan, bukti T. 20, Fotokopi capture akun facbook an, bukti T. 27, Fotokopi gambar diduga Penggugat dengan pria pemilik akun Facebook an, bukti T. 28, Rekaman suara pengakuan anak tentang perselingkuhan Penggugat, bukti T. 33, Rekaman kesaksian anak saat dibawa ke Bandung dalam rangka muallaf dan nikah sirri dengan pria Jepang, bukti T. 34, Rekaman pengakuan anak istri sedang tidur bersama pria Jepang, bukti RT. 35, Rekaman suara istri dengan selingkuhannya pria Jepang, bukti T. 36.

4. Bahwa dalam jawaban dan dupliknya Penggugat Rekonvensi menuntut agar anak Penggugat Rekonvensi dan Tergugat Rekonvensi yang lahir tanggal 19 
Februari 2013 berada dalam pengasuhan dan perawatan Penggugat Rekonvensi tanpa mengurangi hak Tergugat Rekonvensi bisa berjumpa dengan anak tersebut atas sepengetahuan Penggugat Rekonvensi sepanjang tidak mengganggu aktifitas rutin anak tersebut.

5. Bahwa terlebih dahulu Majelis Hakim perlu menjelaskan tinjauan dari sudut hukum Islam mengenai pemeliharaan anak karena Penggugat dan Tergugat beragama Islam yang memiliki prinsip bahwa anak adalah amanah dan titipan dari Allah SWT, kepada suami istri/ayah ibunya dan anak mempunyai hak untuk dilindungi baik keselamatan agamanya, hartanya maupun jiwa raganya oleh kedua orangtuanya lah yang paling bertanggung jawab terhadap keselamatan anaknya dunia akherat dan melindungi mereka dari hal-hal yang tidak baik. Hal ini sesuai dengan firman Allah SWT surat At-Tahrim ayat 6:

Artinya: "Wahai orang-orang yang beriman, lindungilah dirimu dan keluargamu dari api neraka":

Dan salah satu anggota keluarga inti adalah anak, oleh karena itu kedua orang tua hendaknya memperhatikan kebutuhan dan perkembangan anak- anaknya, agar mereka tumbuh menjadi anak yang sehat, baik jasmani maupun rohani, dan berakhlakul karimah serta memiliki intelegensi yang tinggi, anak dapat membuat senang hati kedua rang tuanya, mana kala nak tersebut berbakti kepada mereka, serta taat dalam menjalankan ibadahnya. Namun anak juga dapat membuat susah kedua orang tuanya manakala anak tersebut tidak berbakti kepadanya, serta tidak taat beribadah, sehingga kedua orang tua wajib untuk memelihara dan mendidik anak-anak mereka dengan sebaik-baiknya (vide Pasal 45 ayat (1) Kompilasi Hukum Islam).

6. Bahwa berdasarkan Pasal 1 ayat (2) Undang-Undang Nomor 23 Tahun 2002 tentang Perlindungan Anak adalah segala kegiatan untuk menjamin dan melindungi anak dan hak-haknya agar dapat hidup, tumbuh, berkembang dan berpartisipasi secara optimal sesuai harkat dan martabat kemanusiaan, serta mendapat perlindungan dari kekerasan dan diskriminasi, sehingga hak dan kewajiban anak dalam Undang-undang ini untuk melindungi anak sangat lebih diutamakan, dimana hal ini tetap harus dilakukan meskipun diantara ibu atau ayahnya terjadi perceraian, namun dalam hal memutuskan terhadap pilihan anak harus melihat untuk kemslahatan anaktersebut yang dalam hal ini bukan hanya kemaslahatan dunianya saja akan tetapi juga kemaslahatan akhiratnya.

7. Bahwa berdasarkan Pasal 41 Undang-Undang Nomor 1 Tahun 1974 apabila terjadi perceraian, anak tetap harus terlindungi dan kedua orang tuanya (Penggugat) dan (Tergugat) tetap mempunyai kewajiban untuk memelihara dan mendidik anaknya semata-mata demi kepentingan anak, bukan demi kepentingan orang tua atau salah satu dari orangtuanya (Penggugat) atau 
(Tergugat).

8. Bahwa secara normative penyelesaian tentang sengketa pengasuhan anak telah diatur dalam Pasal 105 ayat (1) Kompilasi Hukum Islam, selengkapnya berbunyi sebagai berikut: "Dalam hal terjadinya perceraian: pemeliharaan anak yang belum mumayyiz atau belum berumur 12 tahun adalah hak ibunya, oleh karena itu pada dasarnya hak ibu (Penggugat) lebih dominan untuk memelihara anak yang belum berusia 12 tahun, sesuai dengan hadits Rasulullah SAW yang artinya: "Barang siapa memisahkan antara seorang ibu dengan anaknya, maka Allah SWT akan memisahkan antara dia dengan kekasih-kekasihnya pada hari kiamat" (H.R. Tirmidzi dan Ibnu Majah).

9. Bahwa penyimpangan atau pengecualian ketentuan Pasal 105 Kompilasi Hukum Islam diatas dapat dibenarkan dengan memahami secara a contrario (mafhum mukhalafah) ketentuan yang diatur dalam Pasal 28 Ayat (1) UndangUndang Nomor 23 Tahun 2002 Tentag Perlindungan Anak, selengkapnya berbunyi sebagai berikut: (1) Orang tua berkewajiban dan bertanggung jawab untuk: a. mengasuh, memelihara, mendidik dan melindungi ana; b. menumbuh kembangkan anak sesuai dengan kemampuan, bakat dan minatnya; dan c. mencegah terjadinya perkawinan pada usia anak-anak; (2) Dalam hal orang tua tidak ada atau tidak diketahui keberadaannya, atau karena satu sebab, tidak dapat melaksanakan kewajiban dan tanggung jawab sebagaimana dimaksud dalam Pasal tersebut diatas dapat dicabut kekuasaannya karena sangat melalaikan kewajibannya terhadap anak dan berkelakuan buruk sekali (Vide Pasal 49 ayat (1) Undang-Undang No. 1 Tahun 1974).

10. Bahwa selain memahami secara a contrario (mafhum mukhalafah) ketentuan diatas, Undang-undang ini juga memberi jalan beralihnya kuasa pengasuhan anak dari ibu (Penggugat) kepada ayah (Tergugat) karena faktor demi kepentingan anak yang berkenaan dengan pertumbuhan mental spiritual sebagaimana diatur dalam Pasal 13 Undang-Undang Nomor 23 Tahun 2002 tentang Perlindungan anak, selengkapnya berbunyi sebagai berikut: (1) setiap anak selama dalam pengasuhan orang tua, wali atau pihak manapun yang bertanggung jawab atas pengasuhan, berhak mendapat perlindungan dari perlakuan: a. diskriminasi; b. eksploitasi baik ekonomi maupun sosial; c. penelantaran; d. kekejaman, kekerasan, dan penganiayaan; e. ketidakadilan; $\mathrm{f}$. perlakuan salah lainnya; (2) Dalam hal orang tua, wali atau pengasuh anak melakukan segala bentuk perlakuan sebagaimana dimaksud dalam Pasal tersebut diatas, maka pelaku dikenakan pemberatan hukum.

11. Bahwa berdasarkan Buku II Edisi Revisi 2013 halam 156 huruf (b) berbunyi: "Pemeliharaan anak yang belum berusia 12 tahun dapat dialihkan kepada ayahnya apabila ibu dianggap tidak cakap, mengabaikan mempunyai prilaku 
buruk yang akan menghambat pertumbuhan jasmani, rohani, kecerdasan intelektual dan agama si anak" dan ketentuan Pasal 7 huruf (a) Undang-Undang Nomor 23 Tahun 2003 tentang Perlindungan anak yakni “setiap anak berhak mengetahui orang tuanya, dibesarkan, dan diasuh oleh orang tuanya sendiri".

\section{Metode Penemuan Hukum Hakim tentang Hak Asuh Anak Akibat Cerai Gugat Dalam Perkara Nomor 0915/Pdt.G/2017/PA.Bgr}

Hakim menggunakan metode konstruksi hukum dalam penemuan hukumnya, yaitu metode pengkongkretan hukum (rechtsvervjnings). Dalam metode ini, hakim dapat menyampingkan pasal yang sudah dianggap tidak sesuai dengan fakta pada saat ini.

\section{SIMPULAN}

Berdasarkan hasil penelitian maka dapat diambil kesimpulan: Pertimbangan Majelis Hakim Pengadilan Agama Bogor dalam pertimbangan hukumnya terhadap perkara Nomor 0915/Pdt.G/2017/PA.Bgr tentang penetapan hak asuh anak akibat cerai gugat adalah, bahwa majelis hakim berpendapat dan sejalan dengan kehendak dari undang-undang tentang perlindungan anak bahwa kewajiban pengasuhan anak haruslah didasarkan demi kepentingan anak dan bukan demi kepentingan orang tuanya. Berdasarkan Pasal 28 ayat (1) dan Pasal 13 Undang-undang Nomor 23 Tahun 2002 Tentang Perlindungan Anak.

Metode penemuan hukum yang digunakan Majelis Hakim dalam memutus perkara hak asuh anak (Hadhanah) ini ialah konstruksi hukum. Kontruksi hukum dilkukan dengan penalaran logis oleh hakim untuk mengembangkan suatu ketentuan dalam undang-undang. Hakim dalam metode penemuan hukum ini diberikan lebih kekuasaannya dalam berijtihad. Konstruksi hukum yang dijadikan dasar dalam hal ini adalah pengkonkritan hukum (rechtservijnings) dalam arti penghalusan hukum, penyempurnaan sistem hukum oleh hakim, yakni ketika sistem Undang-Undang tersebut tidak dapat menyelesaikan masalah secara adil dan sesuai dengan kenyataan sosial. Dalam penghalusan hukum ini, hakim dapat memutus dengan menyampaikan suatu hukum dalam perkara ini yaitu pasal $105 \mathrm{KHI}$ karena hakim menilai Pasal tersebut tidak relevan dengan fakta riil yang ditemukan hakim dalam persidangan karena apabila ketentuan tersebut dijalankan maka perkara tersebut tidak terselesaikan secara adil atau tidak sesuai dengan kenyataan di dalam masyarakat.

\section{DAFTAR PUSTAKA}

Ahmad Mujahidin. 2010. Prosedur Penyelesaian Sengketa Ekonomi Syari'ah di Indonesia. 
Volume I, Nomor 01, Maret 2020

Bogor: Ghalia Indonesia

Amir Syaripuddin. 2006. Hukum Perkawinan Islam di Indonesia. Jakarta: Pernada Medua Group

Amiur Nurdin dan Azhari Akmal Tarigan. 2004. Hukum Perdata Islam di Indonesia (Studi Kritis Perkembangan Hukum Islam dari Fikih, UU No 1/1974 sampai KHI). Jakarta: Kencana.

Beni Ahmad Saebani dan Encep Taufiqurrahman. 2015. Pengantar Ilmu Fiqih.Bandung: Pustaka Setia.

Huzaemah Tahido Yanggo. 2010. Fikih Perempuan Kontemporer. Bandung: Ghalia Indonesia.

M. Yahya Harahap. 2003. Kedudukan Kewenangan dan Acara Peradilan Agama. Jakarta: Sinar Grafika.

Muhammad Bagir. 2008. Fiqh Praktis II: Menurut Al-Qur'an, Al-Sunnah, dan Pendapat para Ualama. Bandung: Karisma.

Subekti. 2001. Undang-Undang Hukum Perdata.

Tihami dan Sohari Sahrani. 2013. Fikih Munakahat. Jakarta: PT Raja Grapindo.

Undang-Undang N0. 23 Tahun 2002 Tentang Perlindungan anak. Bandung: PT. Citra Umbara.

Winaro Surachmad. 1982. Pengantar Penelitian Ilmiah; Dasar, Metoda, Teknik. Tarsito: Bandung Zakaria Ahmad Al-Barry. 